\title{
Portrait of the North East
}

\author{
by Allan Worthy and lan Gouldson, Office for National Statistics
}

\section{Key points}

The North East region:

- is the smallest English region outside London in terms of area

- has a high proportion of land in National Parks and Areas of Outstanding Natural Beauty and is the English region least at risk of flooding

- has the lowest population of any English region, and the slowest rate of growth over the last decade, with the lowest fertility rate

- has the highest death rates for men aged 55 and over of all English regions

- has the highest proportion of White British residents

- has the lowest average house prices and lowest rates of pay of all English regions

- has a high proportion of working-age population with no qualifications, but the highest proportion of Key Stage 4 pupils gaining 5 or more good GCSE passes

- has high rates of unemployment and of economic inactivity due to long-term sickness

- has the highest household crime rate of all English regions, but an average recorded crime rate with the highest rate of detection

- has the highest regional carbon dioxide $\left(\mathrm{CO}_{2}\right)$ emissions per resident in the UK, but concentrated in a few areas with a significant manufacturing base

Allan Worthy is Regional Statistician for the North East Ian Gouldson is Regional Analyst

Tel: 01912296435

Mobile: 07788153723

Email: allan.worthy@ons.gsi.gov.uk

\section{Note:}

Unless otherwise stated the data used in this article were those available at the time of writing. In particular, mid-year population estimates were those released in August 2009.

\section{Introduction}

The North East covers 8,600 square kilometres (sq km) and is the second smallest region in England after London, but its population of 2.6 million in 2008 was the lowest of all regions in England (Online table 1.2). Over 80 per cent of the population live in urban areas with the two main centres of population grouped around the three main rivers in the region. In the north of the region, Newcastle upon Tyne (population 274,000) and Gateshead (population 191,000) straddle the River Tyne and Sunderland (population 280,000) lies on the Wear. In the south of the region, the River Tees flows through Middlesbrough (population 139,000) and Stockton-on-Tees (population 192,000).

The region has a long eastern coastline facing the North Sea, running from its border with Scotland in the north to North Yorkshire in the south. To the west, the Cheviot Hills and North Pennines rise towards Cumbria in the North West region (Map 2.1). The region is easily accessible via the $A 1$ and the East Coast mainline railway as they pass through between London and Edinburgh. From east to west, the A69 connects Carlisle and Newcastle upon Tyne. There are two international airports in the region - Newcastle, which handled 5 million passengers in 2008 (Online table 11.16), and Durham Tees Valley. There is also a ferry service from Newcastle upon Tyne to Amsterdam (Ijmuiden).

Northumberland and Tyne \& Wear is the largest of the sub-regions (NUTS2 areas - Map 2.2) and largely rural, with 1.4 million residents living in 5,600 sq km (Online table 1.2). The population density (people per sq $\mathrm{km}$ ) ranges from under 30 in both Berwick-upon-Tweed and Tynedale to 2,400 in Newcastle upon Tyne (see map on page 97).

Around 60 per cent of the region's agricultural industry gross value added comes from Northumberland and Tyne \& Wear. The area also contains the Northumberland National Park, the Northumberland Coast (an Area of Outstanding Natural Beauty) and Hadrian's Wall (a World Heritage Site).

Tees Valley and Durham is the smaller of the two sub-regions in terms of both population and size, with 1.2 million residents living in 3,000 sq km, although it contains the most densely populated local authority area in the region, Middlesbrough UA, with 2,600 people per sq km (Online table 1.2).

The area has a World Heritage Site in Durham Cathedral, an Area of Outstanding Natural Beauty in the North Pennines and 
Map 2.1 North East: physical features
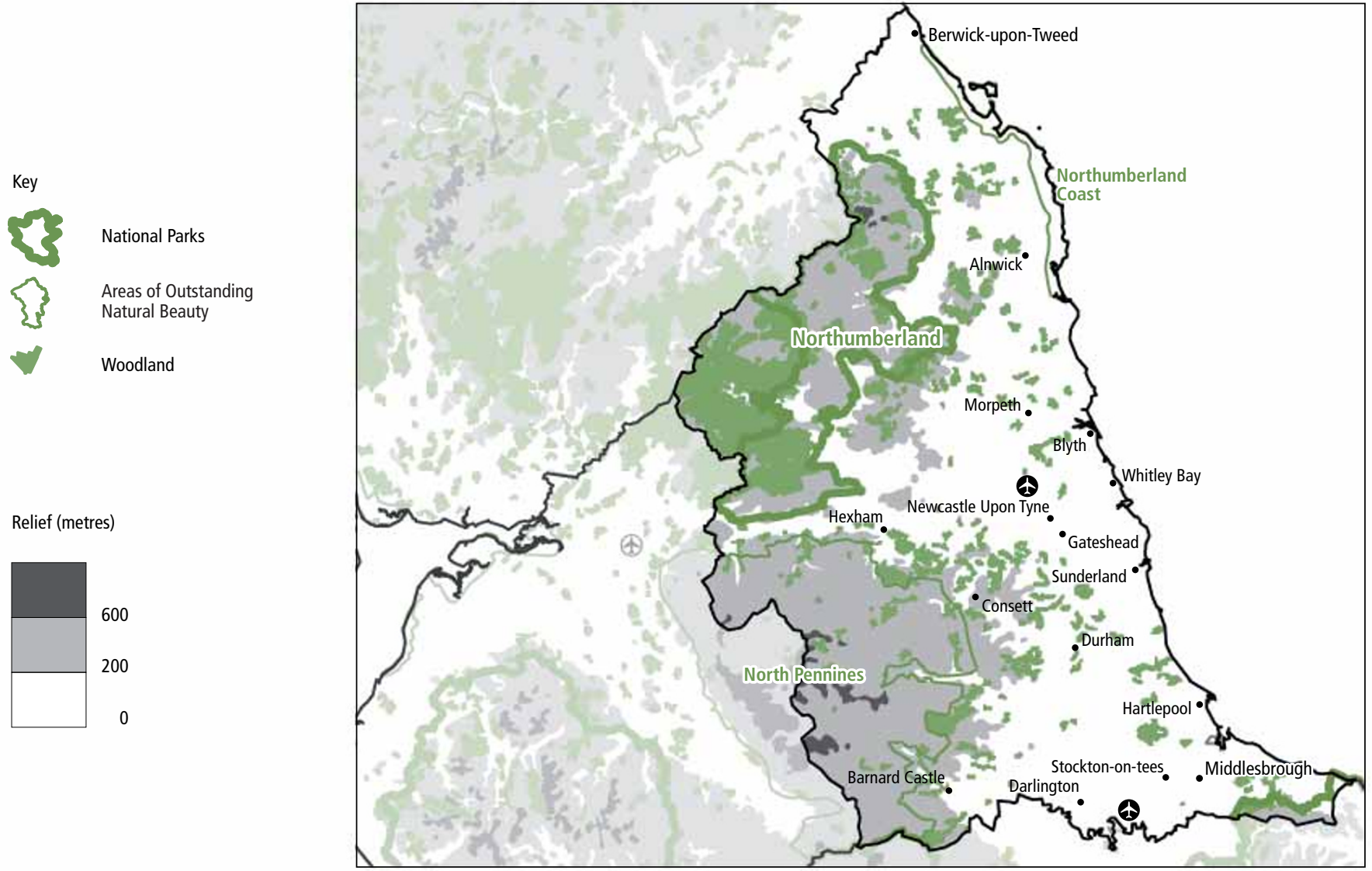

Map 2.2 North East: local or unitary authority, NUTS $2^{1}$ sub-regions and Rural/Urban Definition ${ }^{2}$

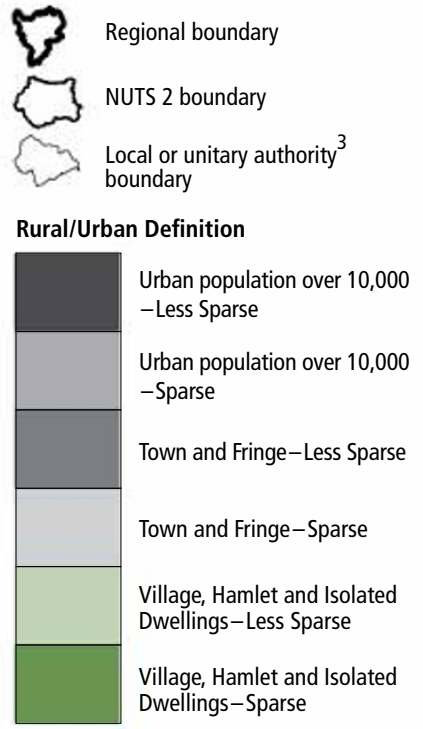

1 Wansbeck

2 Blyth Valley

3 North Tyneside

4 Newcastle upon Tyne

5 South Tyneside

6 Sunderland

7 Chester-le-Street

8 Easington

9 Hartlepool

10 Stockton-on-Tees

11 Middlesbrough

12 Redcar and Cleveland

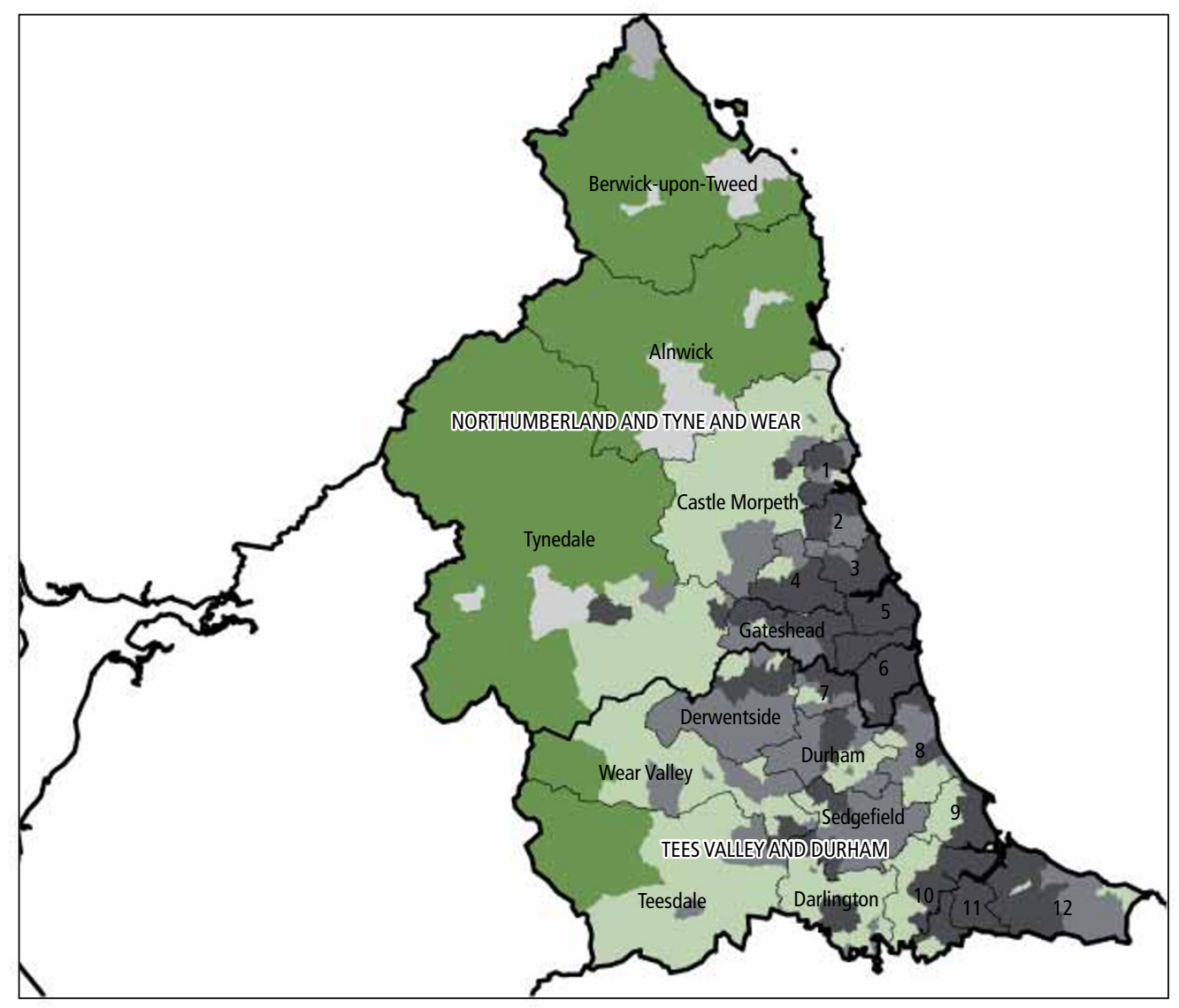

1 Nomenclature of Units for Territorial Statistics, level 2.

2 By Lower Layer Super Output Area.

3 Prior to April 2009. 
also contains most of the region's main chemical industry sites (around Stockton-on-Tees, and Redcar and Cleveland).

One-fifth of the sub-region's gross value added is produced by the manufacturing industry, and almost one-half of the North East's manufacturing industry gross value added is produced in this area.

The North East has been used as a location for numerous books, such as those by Catherine Cookson, and films ranging from the gritty Get Carter (Tyneside) to the whimsical Billy Elliot (Easington) and the distinctly out-of-this-world Alien ${ }^{3}$ (Blast Beach, Seaham). Tourist attractions in the North East include, in no particular order, Alnwick Castle and its gardens, the Angel of the North, Hadrian's Wall, Lindisfarne (Holy Island), Bamburgh Castle, Beamish Open Air Museum, the Bowes Museum, the Baltic Centre for Contemporary Art, Middlesbrough's Institute of Modern Art and numerous other art galleries and museums.

The original Northumbria region designated by the National Rivers Authority (now part of the Environment Agency - see map on page 139) had a long-term average annual rainfall of 831 millimetres between 1971 and 2000, which was very similar to the England average of 819 millimetres (Online table 5.1).

\section{Population}

The North East had a population of 2.6 million in mid-2008, the least in any English region. Its population was less than that of Scotland or Wales but larger than Northern Ireland and amounted to only 4 per cent of the UK population (Online table 1.2).

The region consists of seven unitary authorities (UAs): County Durham, Darlington, Hartlepool, Middlesbrough,

Northumberland, Redcar and Cleveland and Stockton-on-Tees, plus the former metropolitan county, Tyne \& Wear. Tyne \& Wear consists of the metropolitan districts of Gateshead, Newcastle upon Tyne, North Tyneside, South Tyneside and Sunderland. Northumberland and County Durham UAs were created in April 2009. Northumberland UA consists of the former districts of Alnwick, Berwick-upon-Tweed, Blyth Valley, Castle Morpeth, Tynedale and Wansbeck. County Durham UA consists of the former districts of Chester-le-Street, Derwentside, Durham, Easington, Sedgefield, Teesdale and Wear Valley.

Tyne \& Wear had the largest population in the region in 2008 with 1.1 million residents, while the most populous unitary authority in the region was County Durham with 508,000 residents (Online table 1.2). The unitary authority with the smallest 2008 population in the region was Hartlepool with an estimated 92,000 residents. Using the more detailed Local Authority districts that existed pre-April 2009, Sunderland and Newcastle had the highest populations, and the more rural areas of Teesdale, Berwick-upon-Tweed and Alnwick had the lowest populations (Figure 2.3, Online table 1.2).

Population density in the North East in 2008 was 300 people per sq km, ranking it sixth of the nine English

\section{Figure 2.3}

\section{Population: by local authority, ${ }^{1}$ North East, mid-2008 \\ Thousands}

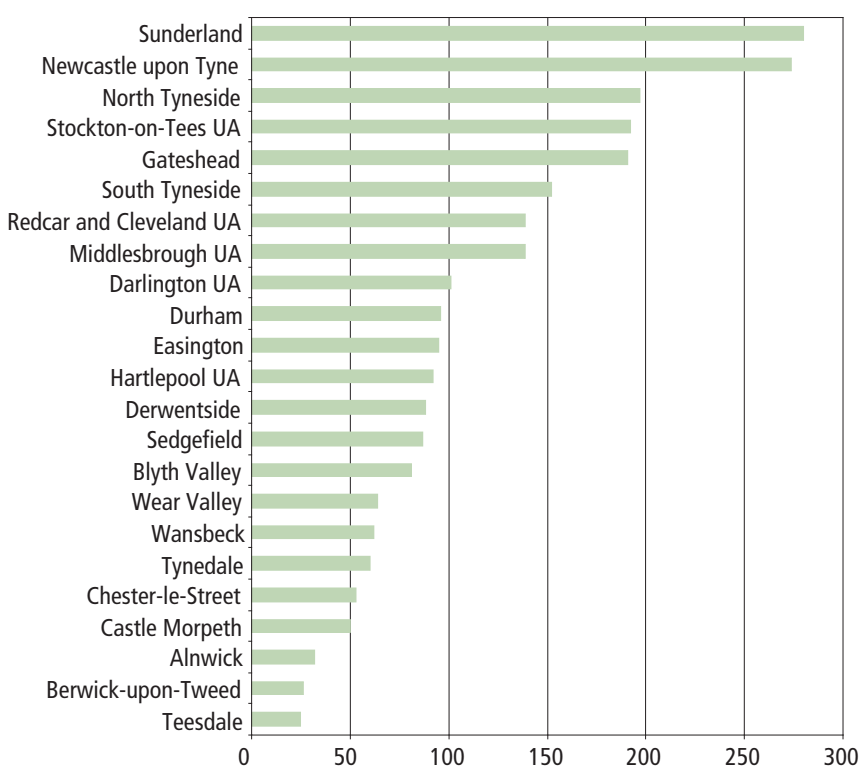

1 Unitary authorities are pre-April 2009

Source: Office for National Statistics

regions, below the England average of 395 but above the UK average of 253. Although the population of the North East was half that of its close neighbour, Scotland (population 5.2 million), the North East's population density was almost five times that of Scotland (66 people per sq $\mathrm{km}$ ). Similarly, although the population of the North East was lower than that of Wales (population 3.0 million), the North East's population density was more than double that of Wales (population density 144 people per sq km). Population density within the North East (see Map 6.1 on page 97) ranged from over 2,600 people per sq $\mathrm{km}$ in Middlesbrough to under 30 in Berwick-upon-Tweed and Tynedale (Online table 1.2).

The population of the region increased by 0.4 per cent $(11,000$ people) between mid-2007 and mid-2008. This was a lower percentage increase than the UK population ( 0.7 per cent) and only the North West had a lower percentage increase than the North East (Online table 10.8).

Natural change, that is births minus deaths, accounted for 3,700 (34 per cent) of the North East increase, which means that most of the population increase was due to migration from other regions or abroad (Online table 10.8). Figure 2.4 shows that within the region, the largest increases due to migration were seen in Durham, Newcastle upon Tyne and Stockton-on-Tees, all of which have large student populations. Decreases in population as a result of natural change were seen in Berwick-upon-Tweed, Tynedale and Teesdale, all of which have relatively high proportions of the population over state pension age, resulting in unchanged or slightly lower populations. Although Castle Morpeth also saw a decrease in population as a result of natural change there was also an 
Figure 2.4

\section{Components of population change: by local authority, ${ }^{1}$ mid-2007 to mid-2008}

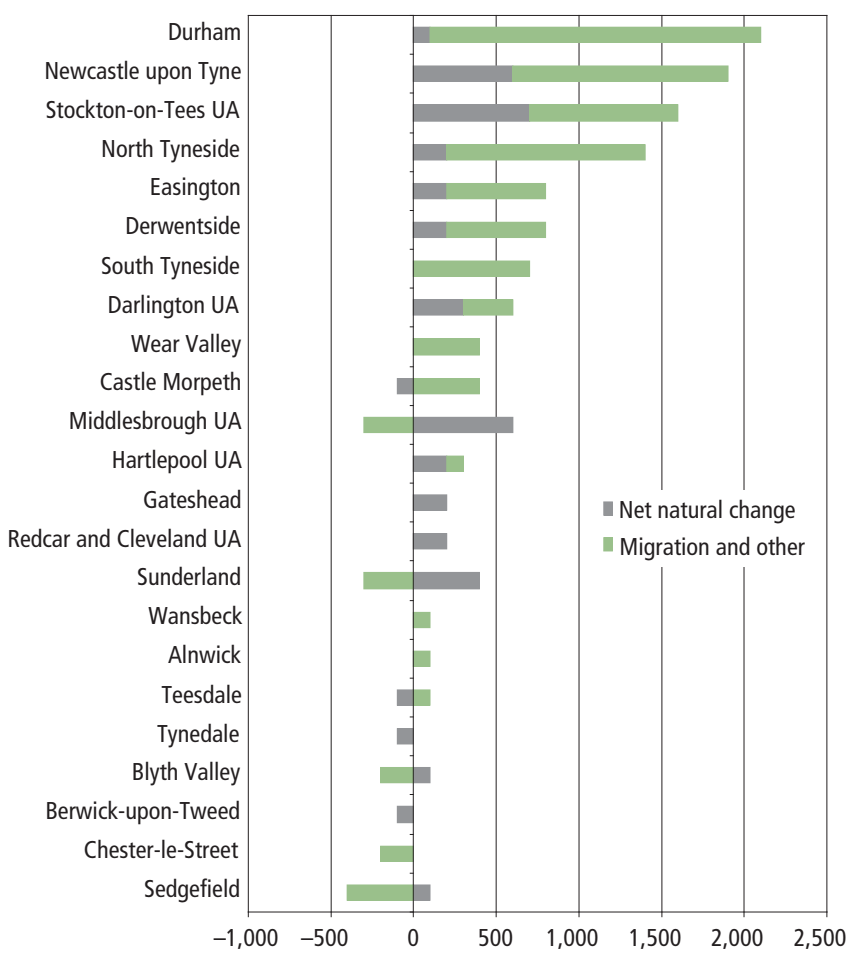

1 Unitary Authorities are pre-April 2009

Source: Office for National Statistics

increase from migration and other changes, resulting in a small overall increase.

Figure 2.5 shows that net inter-regional migration to the region between mid-2007 and mid-2008 was small, with roughly equal numbers of people arriving from and leaving for other regions (about 40,000 in each direction). International

\section{Figure 2.5}

Net migration: by region, 2008

Rate per 10,000 residents

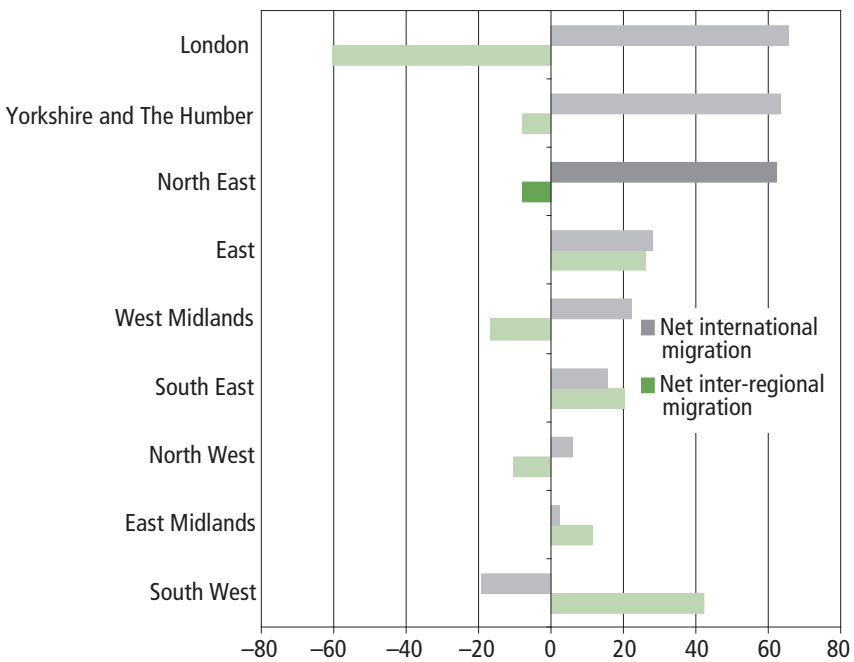

Source: National Health Service Central Register; International Passenger Survey, Office for National Statistics; Home Office migration had a greater effect on the population; only London and Yorkshire and The Humber had higher levels of net international migration per 10,000 residents. However, international migration was at a lower level than inter-regional migration, with 23,000 people arriving and 7,000 leaving (Online table 10.6).

In the period 2001 to 2008 the population of England grew by 4.0 per cent, with the North East showing 1.4 per cent growth. This was the lowest growth of all English regions, and followed a period of decline over most of the previous two decades (Online table 10.1). Within the region, Durham showed the largest percentage increase between 2001 and 2008 at 9.8 per cent, with the population of Middlesbrough decreasing by 1.6 per cent. The 2006-based population projections estimate a 2026 population of 2.7 million for the North East, an increase of 174,000 or 7 per cent on 2006. The equivalent increase for England is 7.9 million or 16 per cent.

In mid-2008 the population structure for the North East was similar to that for the UK (Figure 2.6). The large student centres of Newcastle, Middlesbrough and Durham had a greater proportion of the population in the 20 to 24 age range than elsewhere in the region (Online table 10.2).

The projections for the North East show that by 2026 the population of the age group 0 to 19 will increase by 5,000 while the 20 to 59 age group will fall by 52,000 and the 60 and over age group will increase by 221,000 . In 2006, the female population in the 20 to 59 age group exceeded the number of males by 13,000 . However, projections show that the number of females in this age group will fall faster than the number of males; in 2026 the male population aged between 20 and 59 is projected to exceed females by 6,000. Falls in population of

\section{Figure 2.6}

Mid-year population estimates: by 5 year age band and sex, North East, 2008

Percentages

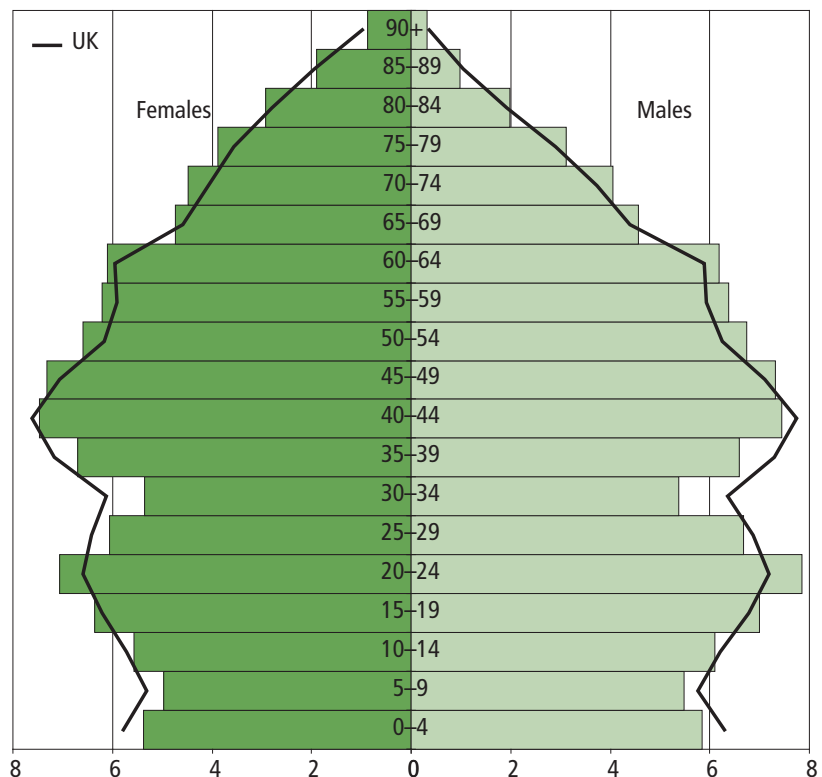

Source: Office for National Statistics 
3,000 (2.0 per cent) are projected for Middlesbrough and 2,000 ( 0.8 per cent) for Sunderland, whereas the largest increases are in North Tyneside with 25,000 (13.0 per cent) and Newcastle with 17,000 (6.3 per cent). Durham is projected to have the highest percentage increase over that period with 14.6 per cent $(14,000)$.

Experimental population estimates by ethnic group show that, within England, the North East had the highest proportion of the population classed as White British - 94 per cent - compared with 84 per cent for England in 2007 (Online table 10.4). Black people comprised 1 per cent, less than the England average of 3 per cent and the lowest proportion of any English region. Asian people comprised 2 per cent, less than the England average of 6 per cent and only the South West had a lower proportion. Within the North East, Newcastle and Middlesbrough had the highest proportions of those describing themselves as other than White British, with 14 and 11 per cent respectively.

In the year ending June 2009, 95 per cent of the region's residents were born in the UK. This was the largest proportion of all of the English regions. Of the 120,000 residents born outside the UK, 12 per cent were born in India, 9 per cent in Germany and 9 per cent in Poland.

There were 30,200 live births in the North East in 2008 (Online table 10.5). The Total Fertility Rate (TFR), which is the average number of children a group of women would have if they experienced the current patterns of fertility throughout their childbearing life was 1.82 in 2007, below the England average of 1.92 and the lowest of the English regions. The lowest TFR in the region was 1.50 for Durham, whilst the highest TFR in the region was 2.16 for Wear Valley (Online table 1.2).

\section{Households and housing}

There were an estimated 1.11 million households in the North East in 2006, an increase of 30,000 (2.8 per cent) on the 2001 estimate. This number is projected to increase by 170,000 (15 per cent) between 2006 and 2026, which is less than any other English region (Figure 2.7, Online table 10.15). The average household size in the region is projected to decrease from 2.26 people in 2006 to 2.09 people by 2026, in line with the average change in England.

Married couples accounted for 47 per cent of households in the North East in 2001 but by 2006 this was estimated to have decreased to 43 per cent. By 2026, the proportion of households consisting of a married couple is projected to fall further to 35 per cent and the proportion of one-person households in the region is projected to increase from 33 per cent in 2006 to 39 per cent in 2026.

There were 1.14 million dwellings in the North East in 2007, which was 44,000 more than in 1997. This represented an increase of 4 per cent, the lowest percentage increase of any English region over that period (Online table 7.1).

In 2007/08 there were around 8,000 new build completions in the North East, of which the majority (over 90 per cent) were for private enterprise. Only 5 per cent were for registered social

\section{Figure 2.7}

\section{Household estimates ${ }^{1}$ and projections: by household type, North East, 2001-2026 \\ Thousands}

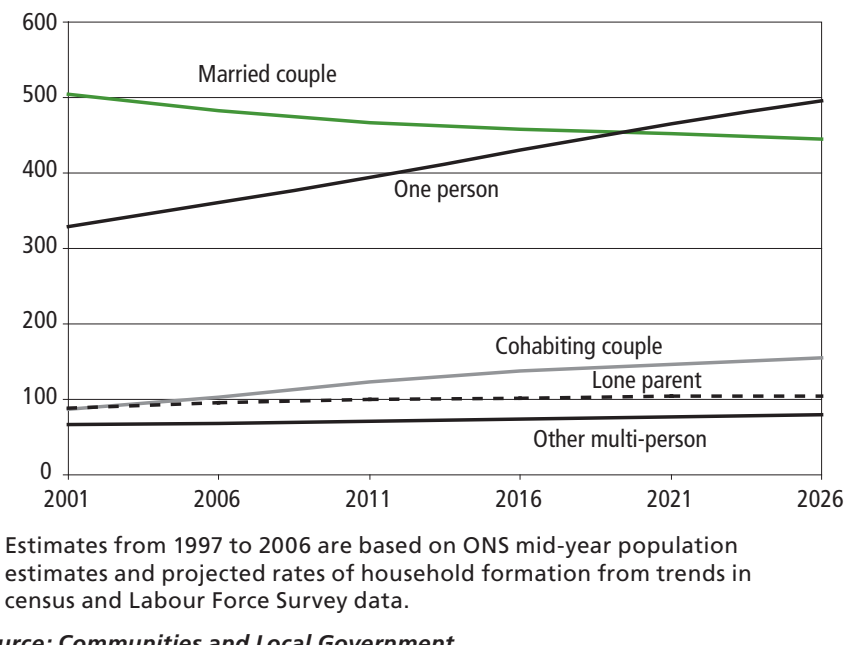

Source: Communities and Local Government

landlords, much less than the highest proportions in London (35 per cent) and the South East (17 per cent) (Online table 7.2). However, the proportion of the North East housing stock rented from local authorities or registered social landlords was 23 per cent in 2007, still among the highest of the English regions although a decline from 31 per cent in 1997 (Online table 7.3).

The median dwelling price in the North East in 2008 was $\mathrm{f120,000}$, the lowest of all English regions and just under 70 per cent of the England average of $£ 174,000$. However, the median price of dwellings in the North East fell by only 1.6 per cent between 2007 and 2008, the lowest fall of any English region, compared with a fall of 2.2 per cent across the whole of England

\section{Figure 2.8}

\section{Median dwelling prices: by local authority, ${ }^{1}$ North East, 2008 \\ $\mathrm{f}$ (thousands)}

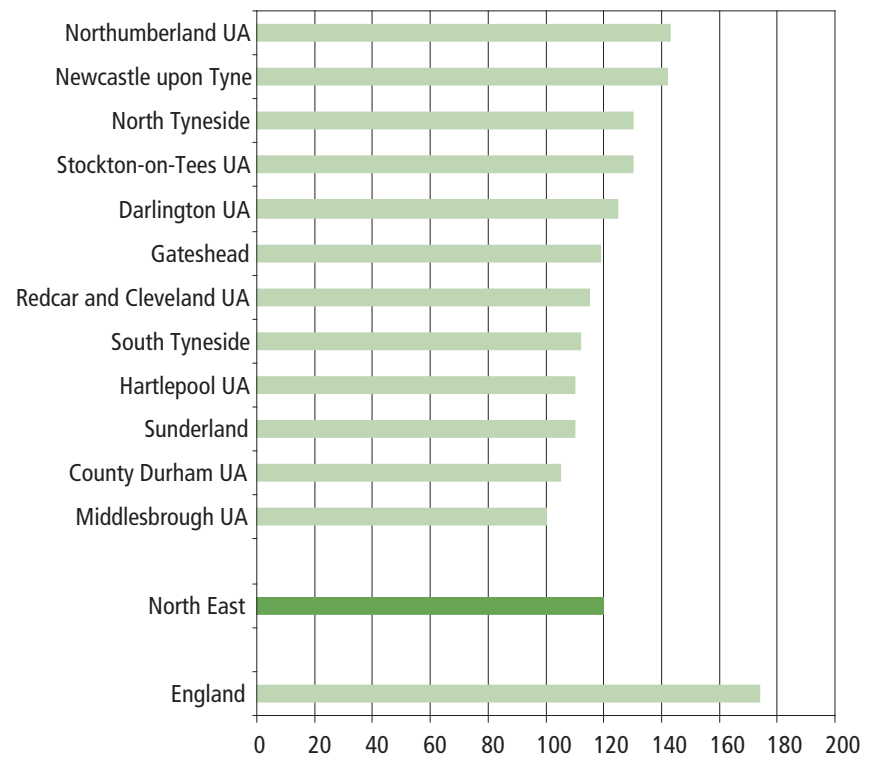

1 Unitary authorities are post April 2009.

Source: Communities and Local Government; Land Registry 


\section{Box 1: Measuring housing affordability}

An important indicator of housing affordability is the ratio of lower quartile house prices to lower quartile incomes.

The lower quartile value for a particular area is determined by ranking all prices or incomes in ascending order and identifying the value below which 25 per cent fall.

The statistics used for lower quartile income are workplacebased annual full-time individual earnings from the Annual Survey of Hours and Earnings (ASHE). The ASHE is based on a 1 per cent sample of employee jobs in April of a given year. It does not cover the self-employed nor does it cover employees not paid during the reference period.

Lower quartile house prices are based on Land Registry data for the first two quarters of a given year. Each ratio is calculated by dividing the house price by income. Data for local authorities in England and Wales can be accessed on the Communities \& Local Government (CLG) website:

www.communities.gov.uk/housing/housingresearch/ housingstatistics/housingstatisticsby/housingmarket/ livetables/

(Online table 7.4). More recent data show that the median price in the North East fell to $f 110,000$ in the first quarter of 2009 before recovering to $f 120,000$ in the second quarter.

Within the region (Figure 2.8), median dwelling prices in 2008 ranged from $£ 100,000$ in Middlesbrough to $£ 143,000$ in Northumberland. Changes in median dwelling prices between 2007 and 2008 ranged from a fall of 6.5 per cent in Redcar and Cleveland to an increase of 4.8 per cent in Hartlepool (Online table 7.4).

One measure of housing affordability is to compare lower quartile house prices against lower quartile earnings of workers in the area (Box 1). The higher the ratio of house prices to earnings, the less affordable are properties in the area. Using this measure, houses were more affordable in the North East than in any other English region. In 2009 the ratio of lower quartile house prices to earnings in the North East was 4.9, compared with the England average of 6.3. Within the North East, the highest ratio in North Tyneside (5.9) was still below the England average. The most affordable housing was in Hartlepool UA and County Durham UA, both with ratios of 4.2. Over the last decade, the North East's ratio increased from 2.8 in 1999 to a high of 5.5 in 2007.

\section{Education and skills}

In 2007/08, 66.4 per cent of Key Stage 4 pupils achieved five or more grades $A^{*}-C$ at GCSE in maintained mainstream schools in the North East. This was the largest proportion of any English region (Online table 4.8). The proportion of 16 -year-olds in post-compulsory education and governmentsupported training in 2006/07 was 84 per cent, the third

\section{Figure 2.9}

\section{Proportion of working age population with no qualifications: by region, 2009 Q2}

Percentages

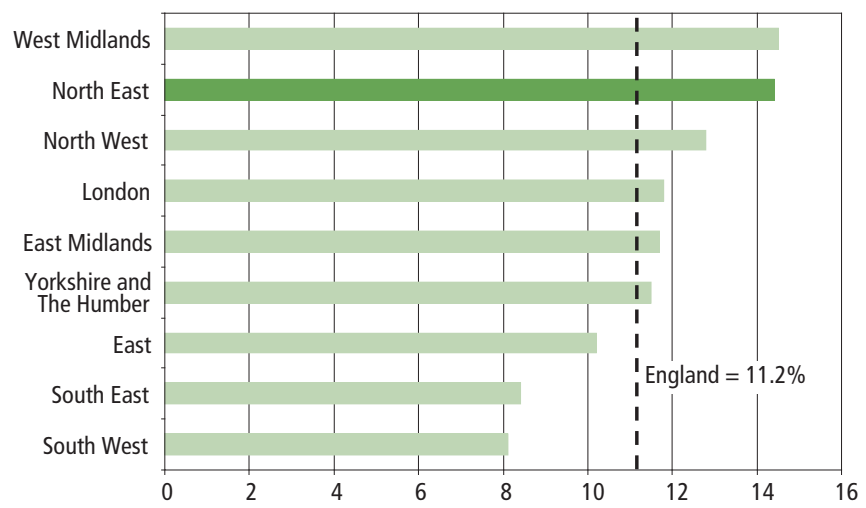

Source: Department for Business Innovation and Skills, from the Labour Force Survey, Office for National Statistics

highest English region after London and the South East, and the same as the England average (Online table 4.10).

In the second quarter of 2009 the proportion of the North East working-age population with no qualifications was 14 per cent above the England average of 11 per cent and slightly below the West Midlands with the highest proportion, 15 per cent (Figure 2.9, Online table 4.14). However, among economically active working-age residents the proportion with no qualifications was only 9 per cent, the same as the England average.

In the second quarter of 2009 the proportion of the North East's working-age population qualified to National Qualifications Framework (NQF) level 4 and above (broadly degree level) was 24 per cent, the lowest proportion of any English region and below the UK average of 30 per cent (Online table 4.14). However, the proportion of economically active North East working-age residents with degree level qualifications in 2008 was 19 per cent, slightly closer to the UK average of 24 per cent, although still the lowest of the English regions and half that of the region with the largest proportion (38 per cent for London residents).

For those economically active and aged 20 to 24 , the proportion qualified to degree level or equivalent or above in the North East in 2008 was 15 per cent, 4 percentage points below the England average of 19 per cent. There were similar gaps between the North East and England proportions at ages 25 to 29,30 to 39,40 to 49 and 50 to retirement age (currently 59 for women and 64 for men).

\section{Labour market}

In the North East, 69.0 per cent of working-age people were employed in the fourth quarter of 2009. This was the lowest rate of all English regions except London's 68.7 per cent, lower than Scotland but higher than Wales and Northern Ireland (Online table 1.1b). The UK average was 72.4 per cent in this quarter. Since the early 1990s, the UK average has been higher 
Figure 2.10

\section{Employment rate:1 North East, 1992 Q4 to 2009 Q $^{2}$}

Percentages

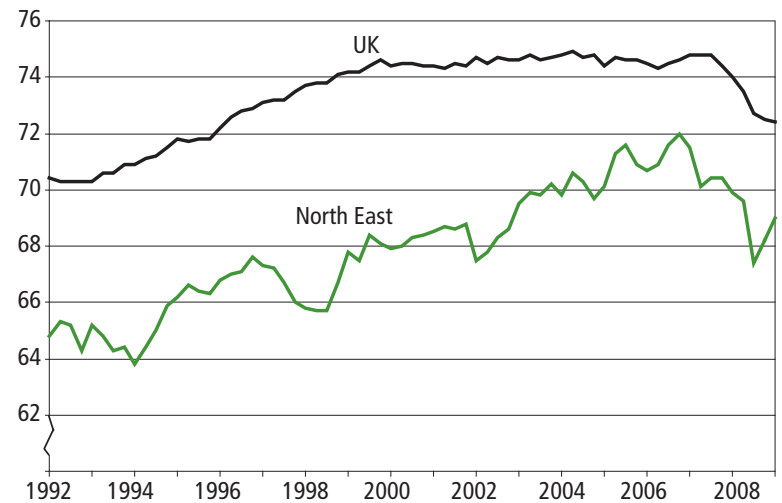

1 Working age.

2 Seasonally adjusted, three monthly data.

Source: Labour Force Survey, Office for National Statistics

than the North East by a margin that ranged from 8 percentage points in 1999 to 4 percentage points in 2009 (Figure 2.10).

Working-age employment rates within the region ranged from 62 per cent in Durham to 85 per cent in Chester-le-Street for the year ending June 2009. The regional average in this period was 70 per cent.

The unemployment rate for residents aged 16 and over in the North East was 9.3 per cent in the fourth quarter of 2009, similar to the West Midlands with 9.4 per cent - one of the highest among the regions of England and countries of the UK (Online table 1.1b). The UK rate was 7.8 per cent. Modelled unemployment rates for local authority districts in the region for the year ending June 2009 (when the unemployment rate for the North East was 8.8 per cent) ranged from 4.8 per cent in Alnwick to 11.0 per cent in Newcastle upon Tyne.

The Jobseeker's Allowance claimant count rate for residents aged 18 and over as a percentage of the estimated workforce in the region (seasonally adjusted) in April 2008 was 4.0 per cent, 1.5 percentage points higher than the UK average of 2.5 per cent. By October 2008 it was 5.0 per cent, 1.9 percentage points higher than the UK average of 3.1 per cent. The claimant count for males increased sharply from October 2008, with month-on-month percentage increases reaching over 10 per cent in November 2008 to January 2009, before starting to level off in March 2009. The claimant count for females showed lower increases until January and February 2009, when month-on-month increases exceeded 10 per cent, before levelling off (Figure 2.11).

In the fourth quarter of 2009, 23.7 per cent of working-age residents were economically inactive, more than the UK average of 21.3 per cent (Online table 1.1b). The North East had a higher proportion of working-age residents who were economically inactive than Scotland and any other English region except London. It was, however, below that of Northern Ireland.

\section{Figure 2.11}

Claimant count: by sex, North East, January 2006 to January 2010

Thousands

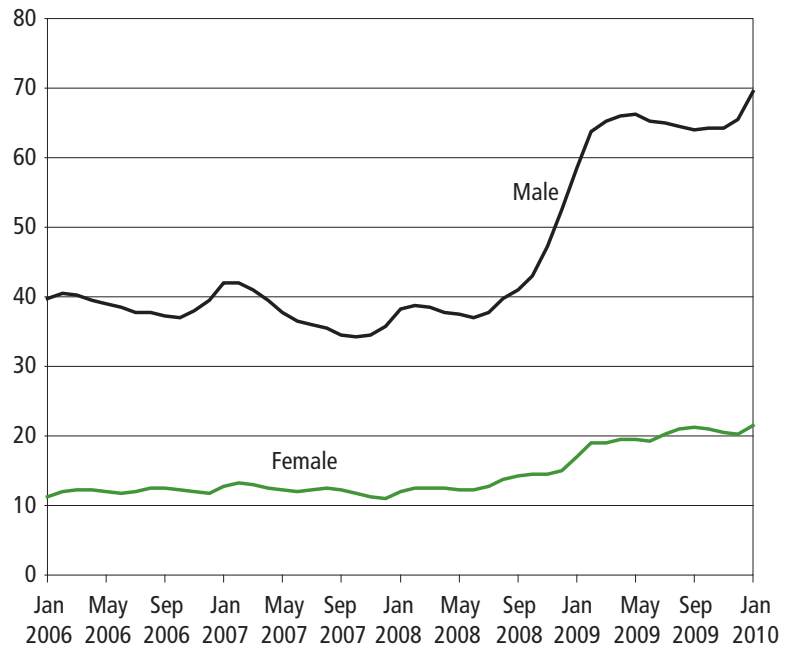

Source: Office for National Statistics

The three main reasons for being economically inactive in the year ending June 2009 were long-term sick at 33 per cent, looking after their family or home at 26 per cent and students at 24 per cent (Figure 2.12). The proportion of working-age people who were economically inactive because of long-term sickness was higher than the UK average of 25 per cent and was the highest of all English regions. Inactivity rates by age in the North East were similar to that of the UK except for the 50 to 59/64 and 60/65 plus age groups, which were the highest of all English regions. Between 2004 and the fourth quarter of 2009, working-age economic inactivity rates in the North East dropped from 26 per cent to 24 per cent.

Median weekly gross earnings, including overtime, of full-time employees resident in the North East in April 2009 were $£ 439$, with $\mathrm{f} 478$ for men and $\mathrm{f} 385$ for women. UK median earnings

Figure 2.12

\section{Reasons for economic inactivity: ${ }^{1}$ North East, 2004 to 2009}

Percentages

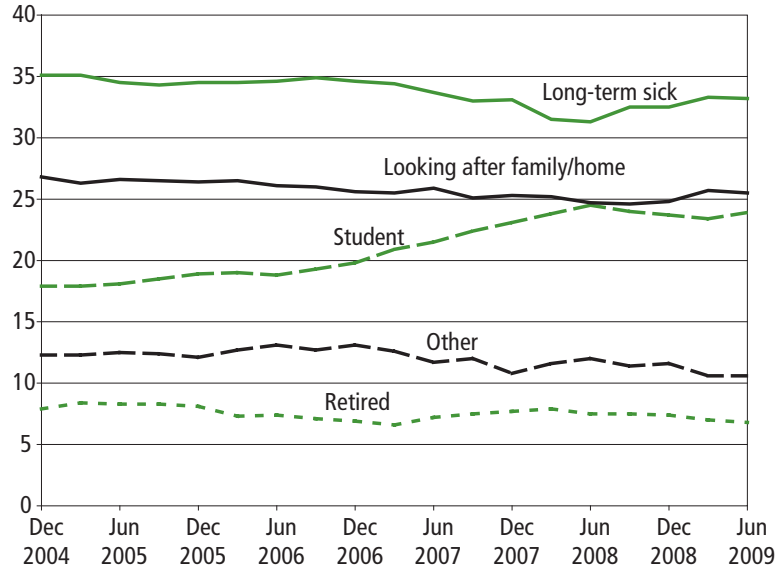

1 As a percentage of all working age economically inactive.

Source: Annual Population Survey, Office for National Statistics 


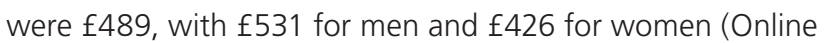
table 9.19). Men in the North East had the lowest weekly pay and full-time hourly earnings of any English region. Only men. Women in the North East had the lowest median weekly gross earnings of any English region. Only Wales had lower median weekly gross earnings and women in the North East had the lowest full-time hourly earnings in the UK.

\section{Economy and industry}

The North East's economy generated $£ 40.9$ billion gross value added (GVA) in 2008, 3.2 per cent of UK total GVA (excluding extra-regio and statistical discrepancy) (Online table 3.1).

GVA per hour worked is the Office for National Statistics' preferred measure of productivity and takes into account factors such as commuting patterns and variations in hours worked. Figure 2.13 shows that GVA per hour worked in the North East was 90 per cent of the UK average in 2008, higher than Northern Ireland, Wales, North West, Yorkshire and The Humber and the West Midlands (Online table 3.2).

GVA per head in the North East was $f 15,900$ per resident, 77 per cent of the UK average, in 2008. This was the lowest of all the English regions, and in the UK only Wales had a lower GVA per head in 2008 (Online table 3.3). Although both subregions (Map 2.2) produced GVA per head below the UK average in 2007, there was a marked difference between the two: Tees Valley and Durham with 69 per cent of the UK average and Northumberland and Tyne \& Wear with 85 per cent (Online table 3.5). At a more local level (NUTS3 - see Reference Map on page 134), Hartlepool and Stockton-onTees' GVA per head relative to the UK fell from 92 per cent in 1997 to 74 per cent in 2007. Tyneside, which produced the largest GVA in the region with $£ 14.9$ billion in 2007, increased

Figure $\mathbf{2 . 1 3}$

Labour productivity: gross value added per hour worked, by region, 2008

UK $=100$

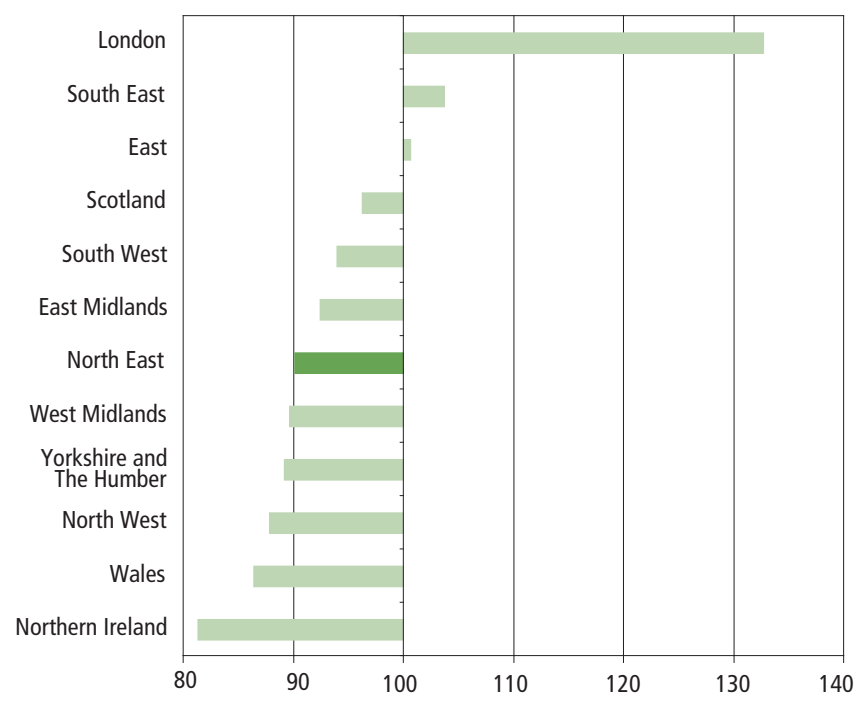

Source: Office for National Statistics

\section{Box 2: Measuring regional economic performance}

When measuring the economic performance of regions or sub-regions, the following should be considered:

Gross Value Added (GVA) is a good measure of the economic output of a region.

GVA per head, which divides output of those working in a region by everybody living in the region, should not be used as an indicator of either regional productivity or income of residents.

GVA per hour worked and GVA per filled job are the preferred measures of productivity of an area.

Gross Disposable Household Income (GDHI) per head is a good indicator of the welfare of residents living in a region.

Productivity, Income and Labour Market indicators should be used together to provide a more complete picture of regional and sub-regional economic performance.

For further information, see the National Statistician's article 'Measuring regional economic performance' which can be found at

www.statistics.gov.uk/cci/article.asp?ID =2103

its GVA per head relative to the UK from 86 per cent in 1997 to 92 per cent in 2007.

In 2007, 17 per cent of the region's GVA was from manufacturing, more than the UK average of 13 per cent. The chemicals, chemical products and man-made fibres industry produced 22 per cent of the region's manufacturing GVA. Only 19 per cent of GVA was from real estate, renting and business activities, less than the UK average of 24 per cent (Online table 3.7).

Short-Term Employment Survey data show that in June 2009 the employment pattern in the North East was similar to that for GVA but the proportion of employee jobs in manufacturing was lower, at 12 per cent, and closer to the UK average of 10 per cent. The proportion of employee jobs in the public administration and defence industry group (8.0 per cent) was the highest of any English region and only Northern Ireland had a higher proportion (Online table 9.4).

Smaller geographies can be compared using the Annual Business Inquiry 2008. The data are for local authority districts that existed prior to April 2009. Figure 2.14 shows that Sedgefield and Derwentside had high proportions of manufacturing employment (28 and 25 per cent respectively). The proportion of manufacturing employment exceeded 20 per cent in three other authorities (Teesdale, Easington and Blyth Valley). Manufacturing employment within the region tends to be relatively specialised. For example, in Sunderland almost half of the 17,700 employees in manufacturing were in the motor vehicles, trailers and semi-trailers industry. Although the 
Figure 2.14

\section{Percentage employed in manufacturing: ${ }^{1}$ by local authority, ${ }^{2}$ North East, 2007}

Percentages

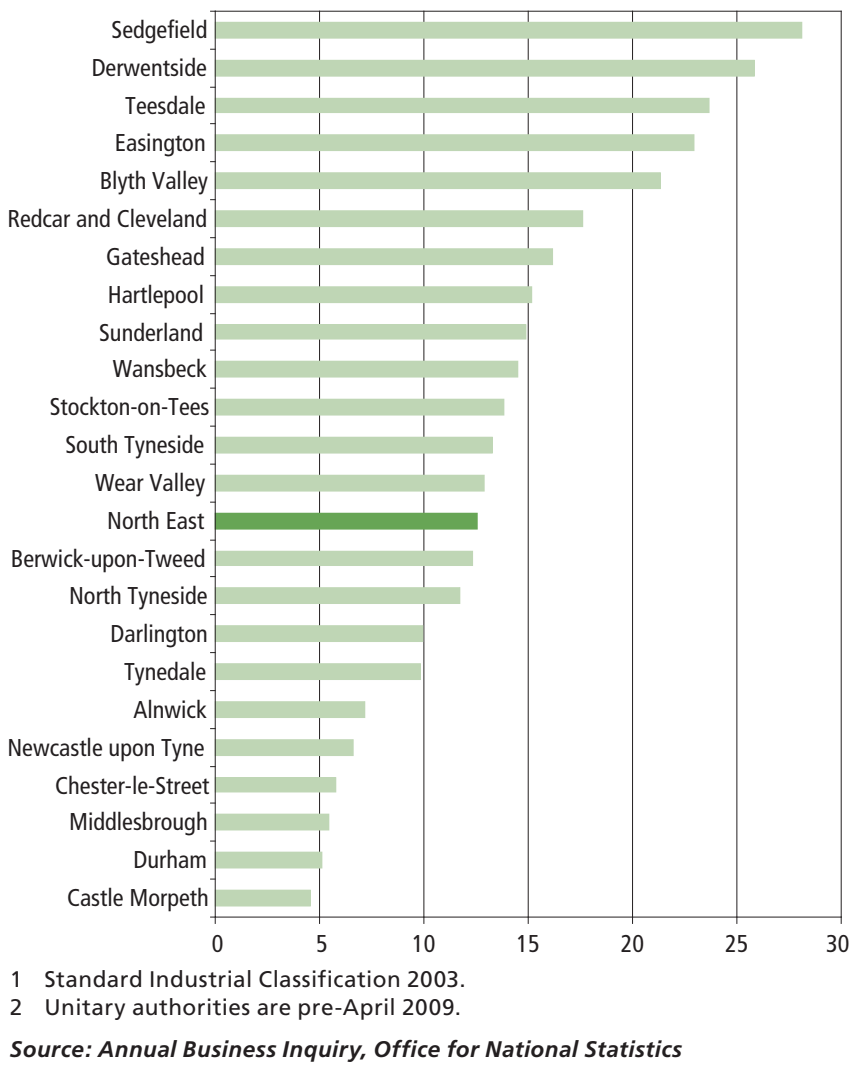

proportion of manufacturing GVA produced by the chemicals industry in the North East in 2007 was over 20 per cent, only 10 per cent of employment was in that industry, concentrated around Stockton-on-Tees, and Redcar and Cleveland. A number of districts have large proportions of employees in public administration and defence, including Castle Morpeth, Durham and Newcastle upon Tyne, which all had in excess of

\section{Figure 2.15}

\section{Business enterprise research and development expenditure as a proportion of gross value added: by region, 2007}

Percentages

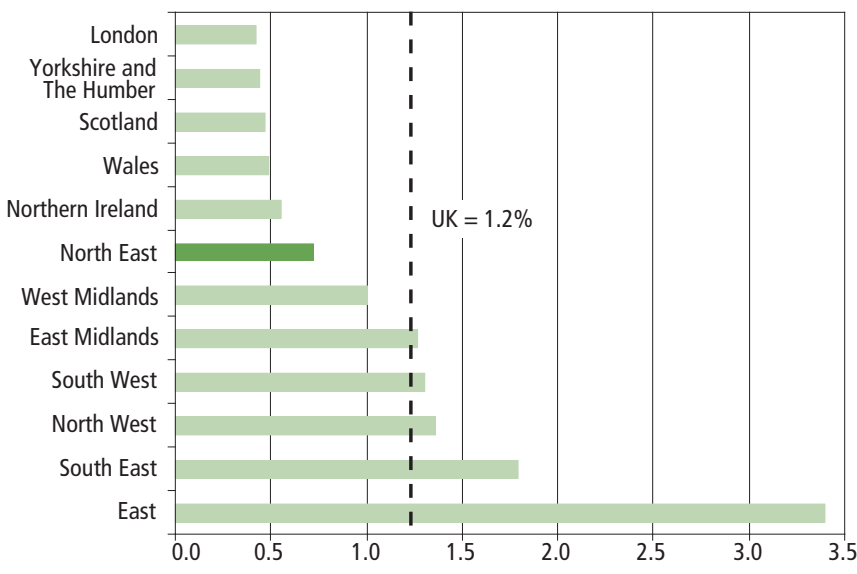

Source: Office for National Statistics
10 per cent employment in that sector. Wansbeck and Middlesbrough both had over 20 per cent of employment in the human health and social work industry.

Employment in the banking, insurance and business services industry in the North East was 15 per cent of the total. Just under one-quarter of total employment in that industry in the region was based in Newcastle upon Tyne. Within the region, the district with the lowest proportion of employment in the banking, insurance and business services industry was Castle Morpeth, with 6 per cent.

Although at a low level compared with other regions, the value of exports of goods by North East businesses (Online table 3.21) expressed as a percentage of GVA, 28 per cent, was the highest of all English regions in 2008. In comparison, the UK average was 19 per cent. Just under half of the North East's total exports of goods were of machinery and transport equipment and around one-third were of chemicals and chemical products.

Business enterprises in the North East spent $\mathrm{f} 310$ million on research and development (R\&D) in 2007. Figure 2.15 shows that as a proportion of GVA ( 0.8 per cent) this was less than the UK average of 1.3 per cent but greater than that of London, Yorkshire and The Humber, Wales, Scotland and Northern Ireland (Online table 3.22).

In the North East, gross disposable household income (GDHI) per head of resident population was $£ 12,200$ in 2007, 85 per cent of the UK average and the lowest of any English region. It was also lower than Wales, Scotland and Northern Ireland (Online table 3.4). Within the North East, GDHI ranged from 80 per cent of the UK average in Sunderland to 99 per cent in Northumberland.

\section{Disadvantage}

According to the 2007 Index of Multiple Deprivation (IMD2007), 34 per cent of Lower Layer Super Output Areas (LSOAs) in the North East were in the most deprived quintile (20 per cent - Box 3) in England, the highest proportion of any English region (Figure 2.16). The North East also had the largest percentage of its population (34 per cent) living in LSOAs in the most deprived quintile in England. The North East had 10 per cent of its LSOAs in the least deprived quintile of England. Only London had a smaller proportion with 9 per cent.

Within the North East, the highest proportions of LSOAs in the most deprived quintile were in Easington with 65 per cent and Middlesbrough with 57 per cent (Figure 2.17). The highest proportions of LSOAs in the least deprived quintile were in Castle Morpeth with 33 per cent and Durham City with 31 per cent. Alnwick, Berwick-upon-Tweed and Tynedale had no LSOAs in the most deprived quintile.

More recently, estimates from the Labour Force Survey show that in the second quarter of 2009, 23 per cent of households in the North East were workless, higher than the other regions of England and higher than Scotland, Wales and Northern Ireland. The England and Great Britain averages were both 17 per cent. 
Figure 2.16

\section{Distribution of LSOA ${ }^{1}$ rankings on the 2007 Index of Multiple Deprivation: by region}

Percentages

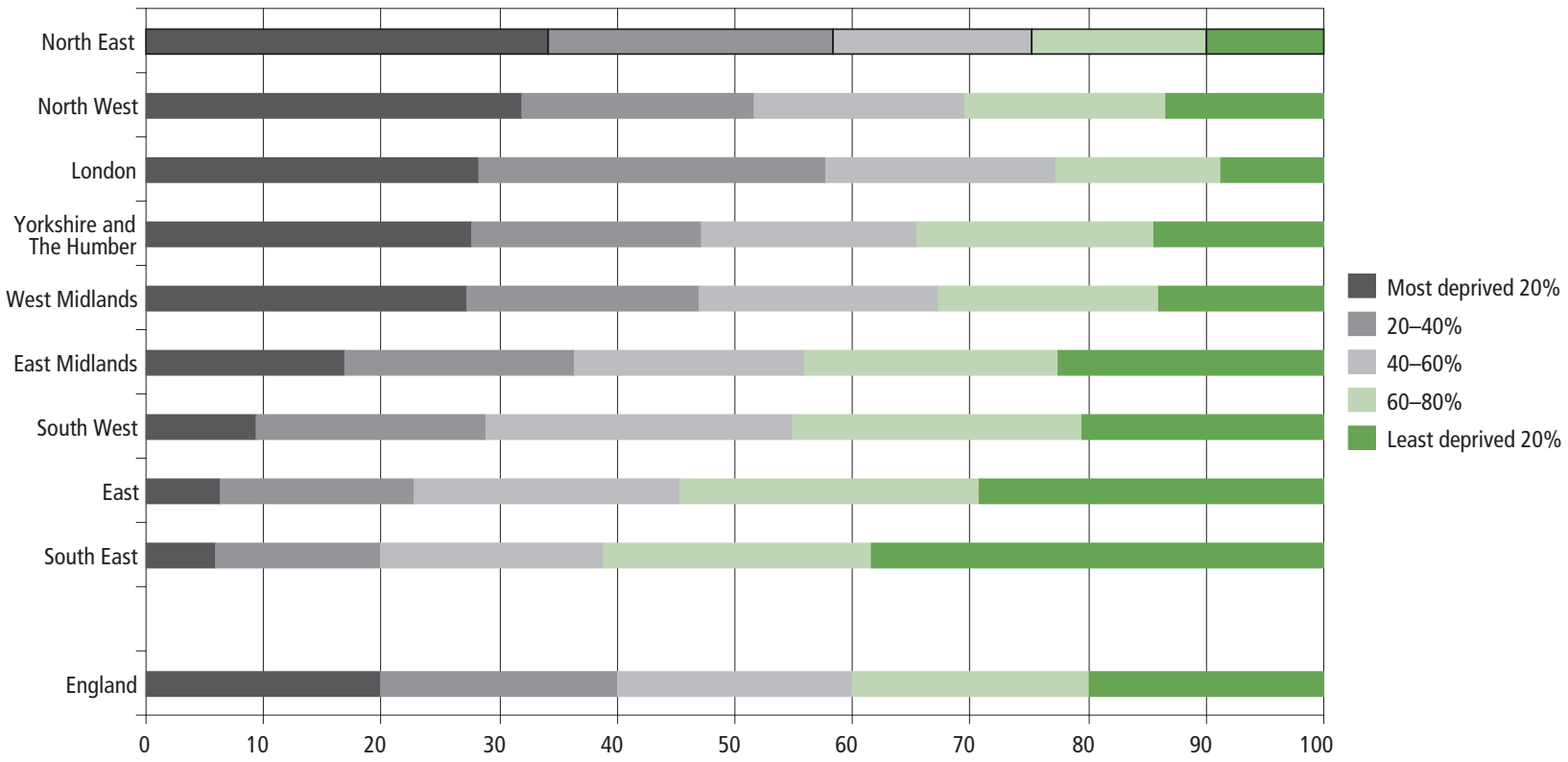

1 Local Layer Super Output Areas

Source: Communities and Local Government

\section{Box 3: Index of Multiple Deprivation 2007}

The Index of Multiple Deprivation (IMD) provides a summary measure of relative deprivation at Lower Layer Super Output Area (LSOA) level in England. The IMD aims to provide a nationally consistent measure of how deprived an area is by identifying the degree to which people are disadvantaged by factors such as low income, unemployment, lack of education, poor health, and crime. Particular points to note:

- not all deprived people live in deprived areas and conversely, not everyone living in a deprived area is deprived; the indicators identify areas with characteristics associated with deprivation - not deprived people

- the indices should not be used as a measure of affluence. A lack of income deprivation does not necessarily equate to affluence

The indices provide a relative measure of deprivation and therefore cannot be used to determine how much more deprived one LSOA is than another.

This article uses the rankings of all LSOAs in England, which have been divided into five equal-sized groups, or quintiles. In England, 20 per cent of LSOAs are in the most deprived quintile and 20 per cent in the least deprived quintile and so on. If an area (region or local authority) had the average distribution of deprivation they would have 20 per cent of LSOAs in each quintile.

For more information on the IMD see the article in

Regional Trends 41, pages 93 to 114, and the Communities and Local Government website: www.communities.gov.uk/indices
Male life expectancy at birth in the North East was also among the lowest in England, similar to the North West and Northern Ireland but above Scotland. Male life expectancy at birth was 76.5 years in the North East compared with 77.5 years in the UK (Online table 6.8).

However, in the period between 1991-1993 and 2006-2008, life expectancy in the North East increased by 4.5 years for males and 3.2 years for females, more than Wales, Scotland, Northern Ireland and any other English region except London. The gap between female and male life expectancy at birth in the North East narrowed from 5.4 years in 1991-1993 to 4.1 years in 2006-2008, in line with the UK average.

Within the region, the highest life expectancy at birth for males was in Tynedale, with 79.6 years, while for females, it was in Berwick-upon-Tweed with 84.3, both in Northumberland. The lowest life expectancy at birth was in Hartlepool with 75.3 years for males and 79.0 years for females.

Age standardised mortality rates for the region show 657 deaths per 100,000 residents in 2008, compared with 592 for the UK. The North East's mortality rate was the highest of the English regions and higher than those of Wales and Northern Ireland but lower than that of Scotland. The North East in 2008 had the highest mortality rate for bronchitis and cancer of all English regions and countries of the UK (Online table 6.4). In the North East in 2008, death rates for ages up to 54 were similar to the UK average, but for both men and women aged 55 and over death rates exceeded the UK average. For males, the death rates for ages 65 and over were the highest of all English regions (Online table 10.10).

In 2007 the North East had the lowest proportions of men and women drinking alcohol on five or more days in the previous 
Figure 2.17

\section{Distribution of LSOA ${ }^{1}$ rankings on the 2007 Index of Multiple Deprivation, for local authorities ${ }^{2}$ in the North East}

Percentages

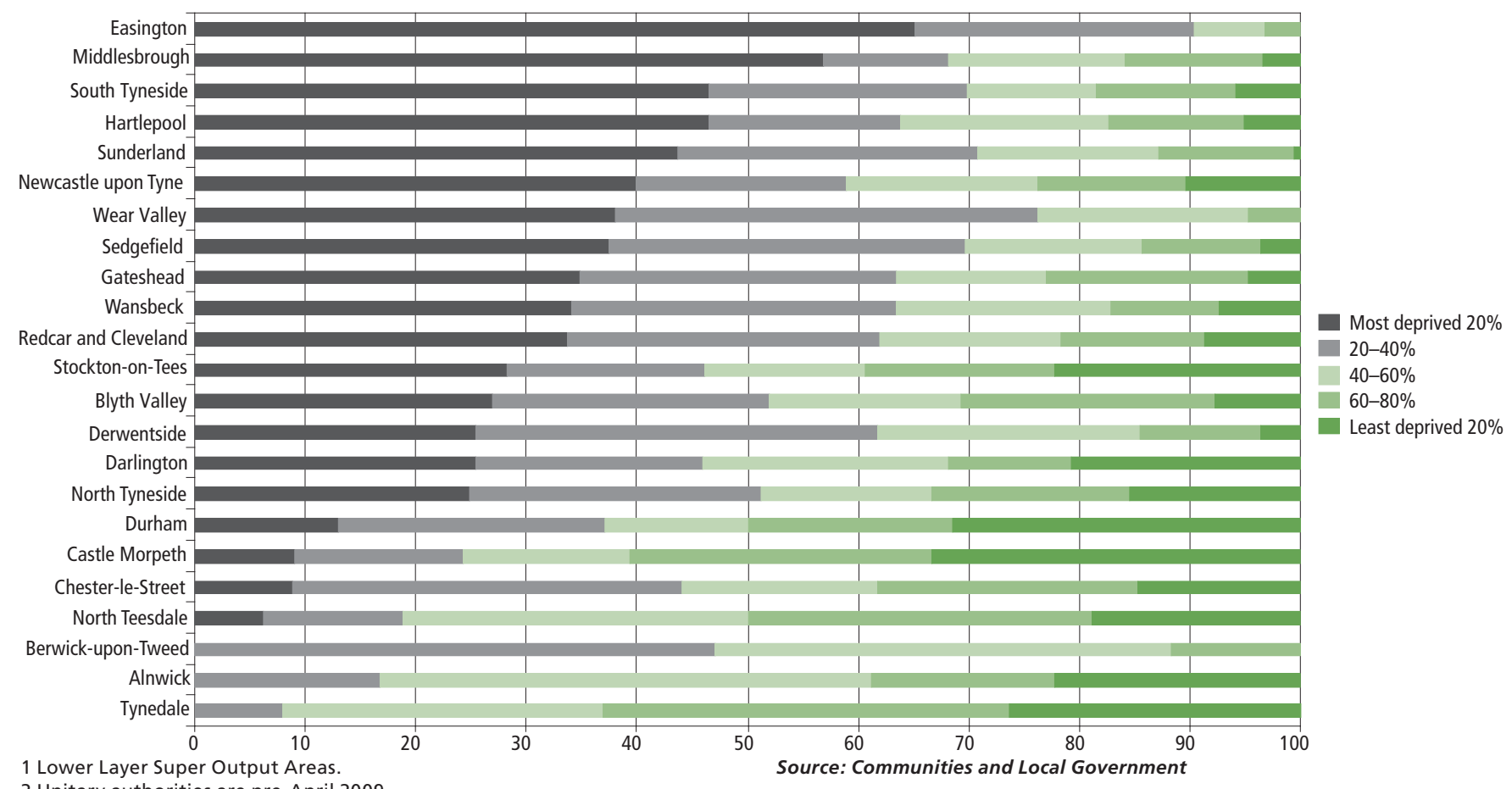

2 Unitary authorities are pre-April 2009.

week of all English regions, at 18 and 9 per cent respectively, compared with the Great Britain averages of 22 and 12 per cent. Only Scotland had lower proportions. The proportion of men in the North East who drank more than four units on at least one day in the week was above the GB average but the proportion drinking more than eight units was below the average. The proportion of women in the North East drinking more than three units on at least one day in the week and the proportion of women drinking more than six units were both below the GB averages (Online table 6.15, Figure 2.19).

\section{Figure 2.18}

Difference in life expectancy at birth between the regions and the UK average, 2006 to 2008 Years

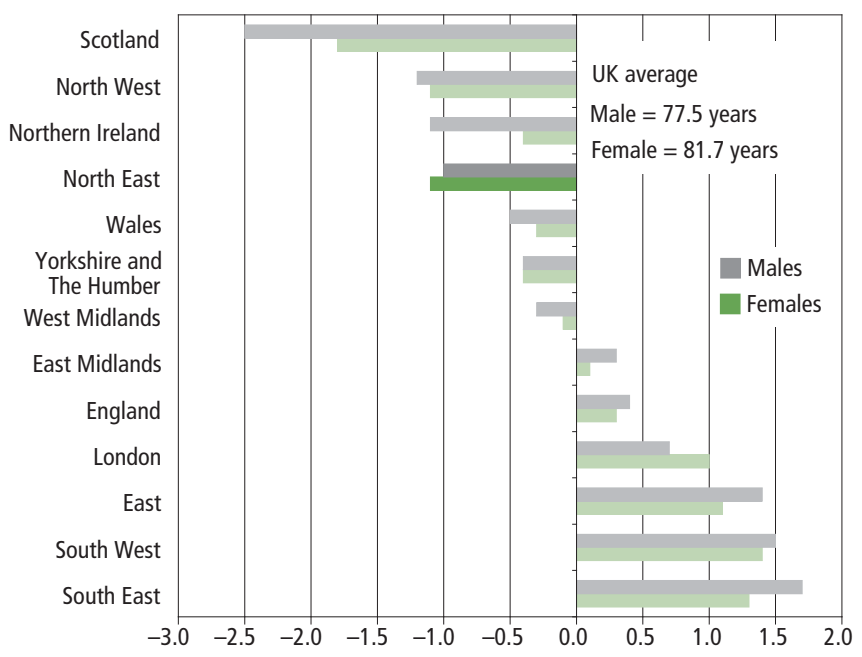

Source: Office for National Statistics
Over one-fifth of North East men smoked cigarettes in 2007, just below the Great Britain average of 22 per cent. Among women, 22 per cent smoked cigarettes, just over the Great Britain average of 20 per cent. The North East had the highest proportion of any English region of men smoking 20 or more cigarettes per day, 9 per cent, and only Northern Ireland had a higher proportion, at 11 per cent. The proportion of women smoking 20 or more cigarettes per day was the highest of any English region or UK country (Online table 6.14).

In common with the North West and Yorkshire and The Humber, in 2008/09 around 10 per cent of 16 to 24-year-olds had used class A drugs, compared with the England average of 8 per cent and the Wales average of 9 per cent (Online table 6.16).

There were 2,400 conceptions in 2008 to women aged under 18 in the region. The under-18 conception rate was 49 per 1,000 women aged 15 to 17 , the highest rate amongst the English regions, compared with the England average of 40 . The proportion of under-18 conceptions that led to a legal abortion was 42 per cent, the lowest of all English regions and well below the England average of 50 per cent (Online table 10.12).

The North East had an infant mortality (deaths under one year of age) rate of 4.2 per 1,000 in 2008 (Online table 6.3), below the UK average of 4.7. The North East region's proportion of live births weighing under $2.5 \mathrm{~kg}$ in 2008 was 7.6 per cent, slightly above the England average, 7.2 per cent, similar to that of Wales (birth weights are not collected at registration by Scotland and Northern Ireland) and below the English region with the highest rate, West Midlands, 8.5 per cent (Online table 6.2). 


\section{Figure 2.19}

\section{Alcohol drunk on 5 or more days in week, men} and women aged 16 or over: by region, 2007

Units of alcohol

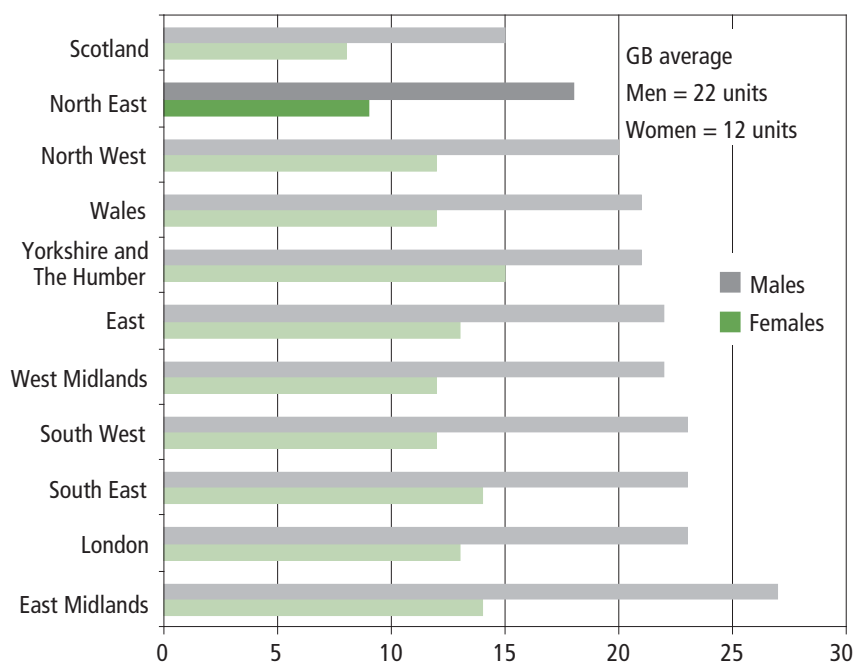

Source: General Household Survey, Office for National Statistics

\section{Transport}

The average distance travelled per person per year in the North East by all modes of transport during 2007 to 2008 was relatively low at 6,400 miles. This was the same as the North West and, within Great Britain, higher than only London, which had the lowest distance travelled, 5,300 miles per person per year. Average mileage in cars and other private road vehicles was 5,250 miles per person per year, or 82 per cent of travel by all modes. Around 14 per cent of the average distance travelled per person in the North East was by public transport, close to the Great Britain average of 15 per cent (Online table 11.4). Only the South West, Wales and Scotland had lower average daily motor vehicle flows on major roads than the North East's 17,100 vehicles per day in 2008 (Online table 11.11).

The usual method of travelling to work for 76 per cent of residents in the fourth quarter of 2008 was a car, van or minibus (Figure 2.20). An estimated 10 per cent of North East residents walked to work (Online table 11.7). Both figures are similar to other English regions, with the exception of London where only 35 per cent of residents used a car, van or minibus.

The proportion of 5 to 16 -year-olds resident in the region that walked to school in 2007 to 2008 was 59 per cent, higher than the Great Britain average of 45 per cent. The average journey length to school was 1.0 miles for 5 to 10 -year-olds (lower than the Great Britain average of 1.6 miles) and 2.2 miles for 11 to 16 -year-olds (lower than the Great Britain average of 3.2 miles) (Online table 11.8).

\section{Environment}

National Park land in the North East amounts to 1,110 sq km. This represents 13 per cent of the region's land area, compared with a UK figure of 8 per cent. A further 17 per cent of the region's land is designated as an Area of Outstanding Natural Beauty (AONB), compared with only 13 per cent for the UK (Online table 5.8).

The original Northumbria region designated by the National Rivers Authority (now part of the Environment Agency (EA)) had a long-term average annual rainfall of 831 millimetres

Figure 2.20

Usual method of travel to work: by region of residence, 2008 Q4

Percentages

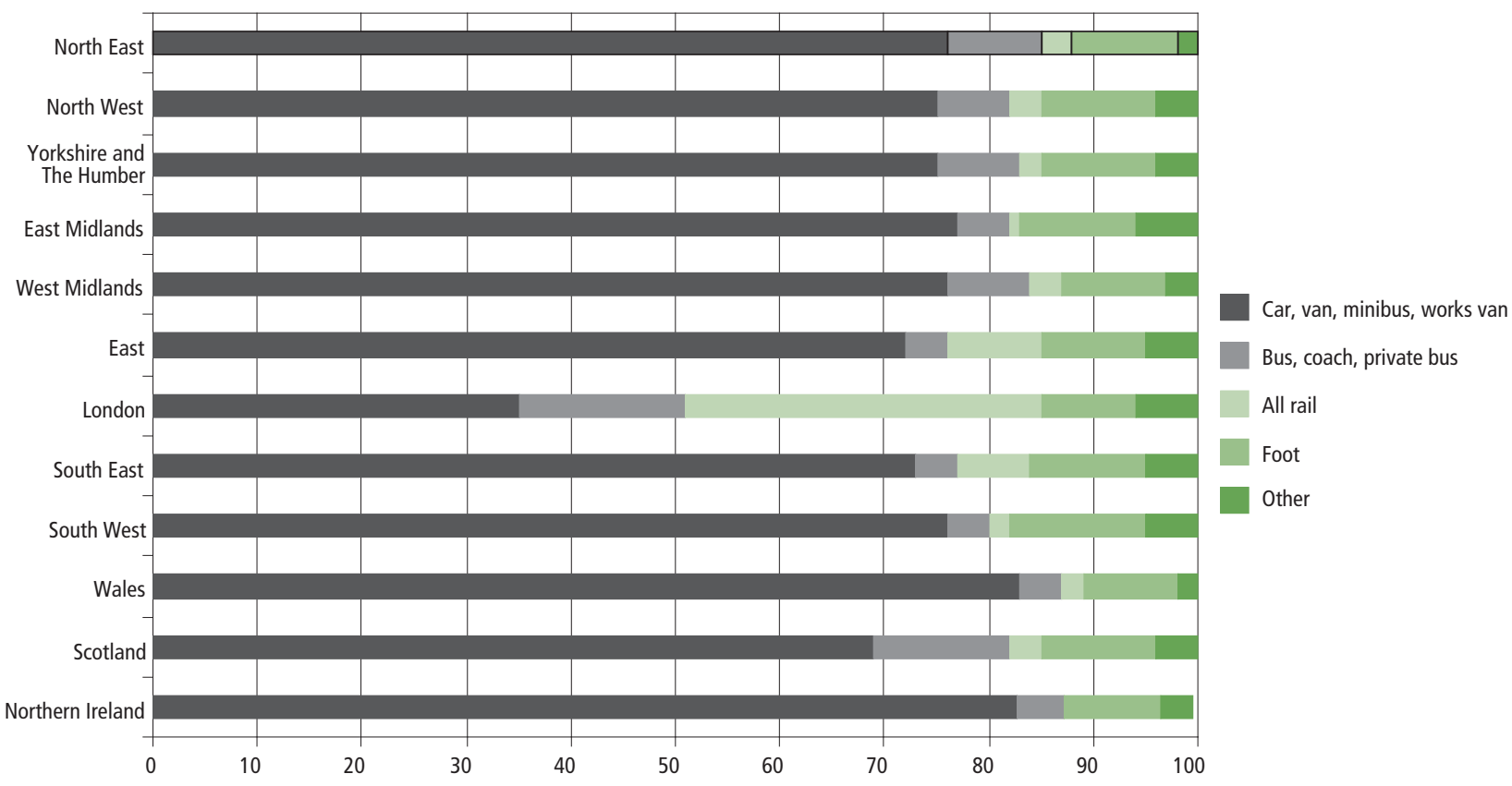

Source: Labour Force Survey, Office for National Statistics 
Figure 2.21

$\mathrm{CO}_{2}$ emissions per resident: by region, 2007

Tonnes per resident

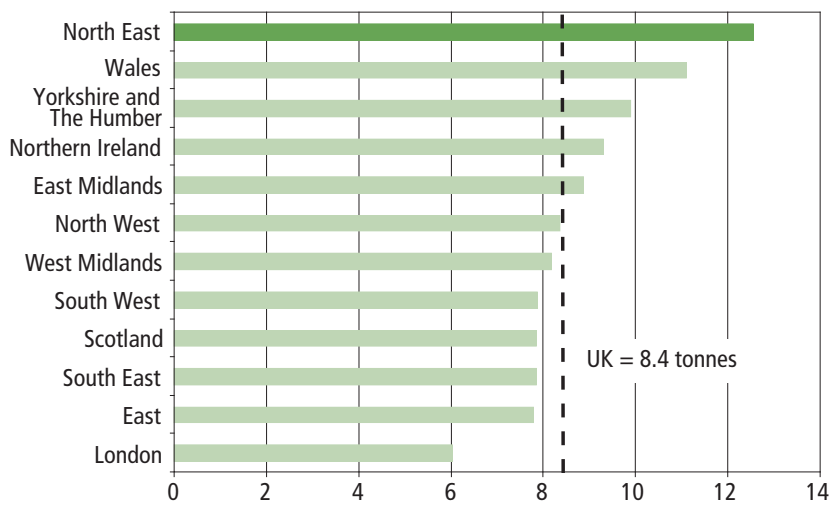

Source: Department of Energy and Climate Change

between 1971 and 2000. This was lower than the UK average of 1,084 millimetres but very similar to the England average $(819 \mathrm{~mm})$ and less than the North West, South West, Wales, Scotland and Northern Ireland, which each had over 1,000 mm. In 2008, annual rainfall in the North East was 34 per cent higher than the 1971 to 2000 average, a larger differential than any other NRA region, Wales, Scotland or Northern Ireland (Online table 5.1).

Although floods in Chester-le-Street, North Tyneside, Darlington, Morpeth, and Rothbury in 2007 and 2008 caused severe damage, a National Assessment of Flood Risk by the EA found that, in terms of the number of properties at risk and the number of people living in floodplains, the North East was the English region least at risk from flooding.

In 2007 the biological quality of 49 per cent of rivers and canals in the North East EA Region (see map on page 139) was classified as good (based on the River Invertebrate Prediction and Classification System (RIVPACS)), compared with an England average of 40 per cent. Also, the chemical quality of 68 per cent of rivers and canals in the North East EA Region were classified as good (based on the General Quality Assessment (GQA) Scheme), compared with the England average of 52 per cent (Online table 5.5).

The North East produced 12.6 tonnes of carbon dioxide per resident in 2007 compared with the UK average of 8.4 tonnes, the highest of all the English regions and above Wales (11.1 tonnes per resident), Scotland (7.9 tonnes per resident) and Northern Ireland (9.3 tonnes per resident) (Figure 2.21, Online table 5.15). The industrial and commercial sector was responsible for 21,100 kilotonnes (66 per cent) of the North East region's 32,200 kilotonnes total $\mathrm{CO}_{2}$ emissions. The highest levels for this sector were in the local authorities of Redcar and Cleveland with 8,200 kilotonnes and in Stocktonon-Tees and Wansbeck, both with 3,200 kilotonnes. These areas have a significant manufacturing base, including the production and recycling of base metals.

In 2007/08 the North East recycled 28 per cent of household waste. This was the second lowest English region after London
(26 per cent), lower than the England average of 35 per cent. However, in 2007/08, the North East recycled more than double the percentage recycled in 2003/04 (Online table 5.11).

\section{Crime and justice}

British Crime Survey (BCS) data show that the North East household crime rate of 3,300 per 10,000 households in 2007/08 was the highest of all English regions, above the England average of 2,700 per 10,000 (Figure 2.22). The proportion of the North East population victimised at least once by violent crime was 4.7 per cent, the highest of all English regions, above the England average of 3.2 per cent (Online tables 2.1 and 2.2).

Recorded crime figures for 2008/09 show a rate of 8,000 recorded crimes per 100,000 population for the North East, well below the highest English region, London, with 11,200 per 100,000 population, and lower than the England average of 8,600 per 100,000 population. With 2,100 recorded instances of criminal damage per 100,000 population in 2008/09, the North East had the highest rate of all English regions, more than the England average of 1,700. On the other hand, the North East had the lowest rate of recorded instances of robbery in England, with 50 per 100,000 population, compared with the England average of 150. The region also had the lowest rate of fraud and forgery, with 180 instances per 100,000 population, compared with the England average of 300 (Online table 2.3).

The BCS does not provide results at local authority level but the recorded crime figures include a set of BCS comparator offences for 2008/09 which covers about 60 per cent of all recorded crimes and allows differences at a local level to be highlighted. Within the North East, Middlesbrough had the highest rates of BCS comparator offences across all categories and in total with 85 per 1,000 population, whereas Teesdale had the lowest rate of recorded crime, with 15 BCS comparator offences per 1,000 population (Online table 2.4).

\section{Figure 2.22}

\section{Crimes committed against households: by region, 2007/08}

Rate per 10,000 households

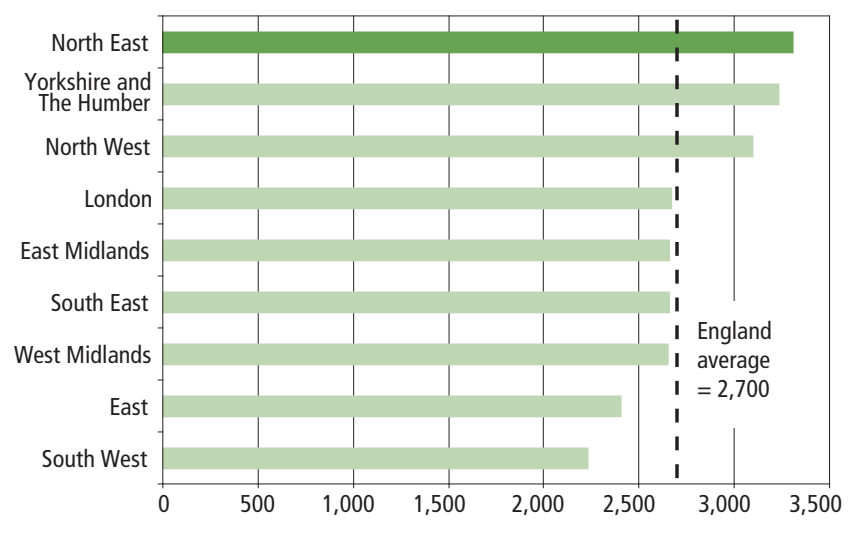

Source: British Crime Survey, Home Office 
Detection rates in the North East in 2008/09 were the highest among the English regions across all categories, with 37 per cent in total (the ratio of offences cleared up in the year to offences recorded in the year) compared with the England average of 28 per cent (Online table 2.5).

Rates of conviction in the North East were among the highest of all English regions, with 1,700 per 100,000 population in the 10 to 17 age group, compared with an England average of 1,200. Furthermore, for the 18 and over age group, the rate of conviction in the North East was 900 per 100,000 population, compared with the England average of 700 (Online table 2.8).

Immediate custodial sentences in 2007 comprised 6 per cent of outcomes for men and 2 per cent for women, both below the England averages of 8 per cent and 3 per cent respectively. Of those immediate custodial sentences, 67 per cent for men and
76 per cent for women were for a year or less, both less than for England at 71 and 81 per cent respectively (Online tables 2.9 and 2.10).

The number of Anti-Social Behaviour Orders issued by courts in the North East has dropped from 268 in 2005 to 122 in 2007. In common with other areas of England there has been a move away from ASBOs to using other tools and judicial powers. However, at 54 per cent, this was the largest percentage fall of any English region (Online table 2.6).

The March 2009 police service strength of 7,500 officers on ordinary duty corresponded to one officer to 350 people in the region. This was fewer residents per police officer than the England average of 380. The North East also had a smaller ratio of special constables than the England average, 58 per 1,000 police officers compared with 99 per 1,000 across England (Online table 2.13). 